\title{
Presidential Capital and the Supreme Court Confirmation Process
}

\author{
Timothy R. Johnson \\ University of Minnesota \\ Jason M. Roberts \\ University of Minnesota
}

The Supreme Court nomination and confirmation process has become one of the most contentious aspects of American politics in recent years, representing a seismic struggle between the president and the U.S. Senate over the ideological makeup of the nation's highest court. Existing research focuses on how the ideological compatibility of the president and the Senate affects the ideology of the president's nominees. However, little work addresses whether presidents can overcome an ideologically hostile Senate by spending political capital to support a nominee. As such, we examine the president's public expenditure of capital to obtain confirmation for Supreme Court nominees facing a Senate that is reticent to confirm. By content analyzing public statements made by presidents during confirmation battles we find strong support for the hypothesis that presidents strategically "go public." Further, this strategy has a marked influence on presidents' ability to win confirmation for their most important nominees.

"Tell your senators to resist the politicization of our court system. Tell them you support the appointment of Judge Bork."

—President Ronald Reagan, 1987

\begin{abstract}
$\mathbf{S}$
ince President Reagan's public defense of Robert Bork (and arguably since President Nixon's nominations of Clement Haynsworth and G. Harrold Carswell), the Supreme Court confirmation process has become one of the most contentious aspects of American politics. It represents a seismic, and oftentimes public, struggle between the president and the U.S. Senate over the ideological makeup of the nation's highest court. This political wrangling is fueled by the fact that both the president and the Senate believe their institution plays the key role in determining the next Supreme Court justice. While President Nixon believed the Senate should always acquiesce to the president's choices (Maltese 1995, 12), former Senate Judiciary Committee Chair Patrick J. Leahy (D-VT) points out that the Senate's role, “. . . is advise and consent. It isn't advise and rubber-stamp."
\end{abstract}

\footnotetext{
${ }^{1}$ Quoted in The Washington Post March 15, 2002, Page A-01. While Senator Leahy's comments came in the wake of the Senate's rejection of Charles Pickering to the U.S. Circuit Court of Appeals,
} 
Because of the magnitude of Supreme Court nominations, as well as the political battles that often ensue over them, political scientists and legal scholars have studied this process generally (Watson and Stookey 1995) and have investigated specific aspects of it, including how presidents choose nominees (Nemacheck and Wahlbeck 1998), how the ideological relationship between the president and the Senate affects the ideology of the eventual nominee (Moraski and Shipan 1999), and what drives individual senator's confirmation votes (Segal, Cameron, and Cover 1992). ${ }^{2}$

Additionally, scholars have addressed the rhetorical style that presidents use to support their Supreme Court nominees, but the decision to "go public" (Kernell 1997) in order to assist a nominee has not been fully analyzed. Such a strategy seems crucial to answering questions about how presidents attempt to secure confirmation for their most important nominees-especially when it is clear that winning Senate confirmation will be a difficult task. While Krutz, Fleisher, and Bond (1998) demonstrate the importance of presidential statements at the time of nomination, to this point there has been no systematic analysis of "going public" for the entire nomination and confirmation process. This lack of research may reflect the fact that scholars simply assume presidents always use their bully pulpit during the confirmation process, but assuming they do so and systematically demonstrating that they do are different questions. No empirical evidence yet exists to demonstrate such a claim.

In this paper we seek to fill this void in the literature. Explicitly, we focus on all Supreme Court nominations between 1949 and 1994 and content analyze all presidential public statements between the time a nomination is made public and the date when the Senate takes action on the nomination. We then use these data (1) to provide detailed insight into the president's use of the bully pulpit during the Supreme Court confirmation game, and (2) to determine how this public support helps presidents win these highly political battles. ${ }^{3}$

the sentiment applies to Supreme Court nominees as well. Nixon fully argued that, "If the Senate attempts to substitute its judgment as to who should be appointed, the traditional constitutional balance is in jeopardy and the duty of the president under the Constitution is impaired. What is at stake is the duty of the preservation of the traditional constitutional relationships of the president and the Congress" (quoted in Maltese 1995, 12).

${ }^{2}$ Others have provided insights into the confirmation process beyond what transpires during Supreme Court confirmations (e.g., Mackenzie 1981, 2001). These works help us understand the general dynamic between the president and the Senate, but do not directly address the question in which we are interested.

${ }^{3}$ Certainly, there are other ways presidents could invoke their capital to try to win confirmation for their chosen nominees. For instance, we could think about strategies presidents employ behind the scenes. It was widely reported that President Clinton decided to appoint Stephen Breyer in part because he had the support of key Republicans in the Senate including the Minority Leader (Robert Dole) and Orrin Hatch - the ranking member of the Senate Judiciary Committee (Idelson 1994b, 1305)—while President Reagan observed that Anthony Kennedy “... seems to be popular with many senators of varying political persuasions ..." (Reagan 1987). This strategy does not always work, however. Clement Haynsworth's confirmation had been "guaranteed" by Senator Eastland (the Judiciary committee chair), as well as by Senators Everett Dirksen and Ernest Hollings. Yet, in the 


\section{Existing Literature and Theory}

To derive hypotheses about when presidents are likely to go public to secure confirmation for their most valued nominees, we turn to two bodies of research that analyze relationships between presidents and Congress. First, we are interested in the literature that focuses on when presidents are most likely to go public to support their general policy agenda in Congress. Second, we focus on the literature that seeks to explain presidential and Senate behavior during the Supreme Court nomination and confirmation process.

\section{When and Why Presidents Go Public}

In his famous treatise on presidential power, Neustadt argues that a president's greatest resource is the power to "convince such men [or women] that what the White House wants of them is what they ought to do for their sake and on their authority" (1990, 30). Since this pathbreaking work, a burgeoning literature has developed that seeks to explain the ability of the president to set both the public agenda and the congressional agenda (Cohen 1995; Edwards and Wood 1999; Ostrom and Simon 1988), as well as how a president's activities affect his public approval ratings (Brace and Hinckley 1993). Building on much of this literature, Kernell (1997) claims a variety of factors - including the presidential selection process, divided government, and the advent of electronic media-have led presidents to change the way they try to persuade Congress. Rather than rely on phone calls, back-room negotiations, and compromise, Kernell suggests that presidents have increasingly turned to public statements to "go over the heads" of members of Congress and to persuade reluctant members.

Kernell presents an array of fascinating anecdotes that describe the benefits and limitations of "going public" as a political strategy. For instance, Ronald Reagan scored odds-defying budget victories early in his first term by imploring citizens to ". . . contact your senators and congressmen. Tell them of your support for this bipartisan proposal" (Kernell 1997, 150). The point is that by "going public" presidents attempt to translate popular electoral support into congressional support. As a member of the Reagan administration noted during the controversy over the failed Robert Bork nomination, "Damn it, Ronald Reagan carried 49 states, and if the voters didn't like his Supreme Court appointments, they would have voted for the other guys."

end, the Senate failed to confirm Haynsworth. In general, while behind the scenes maneuverings are a form of spending capital, we argue that most of these negotiations take place prior to a nomination being made, and do not always produce the intended result. Additionally, these expenditures of capital are not measurable and do not have any public bite. That is, a private call from the president may elicit support but there are no public consequences if a senator does not acquiesce to a call. However, if a president openly calls on a senator, or on the whole Senate, there can be some political bite if the Senate chooses to ignore the president.

${ }^{4}$ Quoted in The New York Times July 9, 1987, page A-24. 
In general, Kernell argues that "going public" is a powerful tool, but he and others have noted the limitations of such a strategy. Edwards and Wood (1999) find that the ability of the president to focus the congressional or media agenda is not unconditional across issue areas, while Sinclair (1991) points out how "going public" failed President G. H. W. Bush in his budget fights with a Democratic Congress. Additionally, Kernell is quick to contrast Reagan's early successes with occasions late in his tenure where his public appeals fell on deaf ears and were ultimately ignored by Congress.

One of the key limitations of going public is the extent to which doing so closes off bargaining options for the president and Congress (Kernell 1997, 4). If the president draws a line in the sand on a budget or policy he strictly limits his ability to compromise, and effectively constrains his policy choices, because he can no longer cooperate without appearing to have given in to Congress. Perhaps most relevant for our study, Massaro (1990) notes that President Nixon's strategy of going public to entice the Senate to confirm Harrold Carswell backfired. ${ }^{5}$

While the risks of going public may not make it the best strategy for all issues facing presidents, it seems particularly well suited for Supreme Court nominations. Indeed, Supreme Court nominations are important, high profile, events that evoke a great deal of attention from both the president and the Senate. As President Nixon argued, "The most important appointments a President makes are those to the Supreme Court of the United States" (quoted in Segal 1987), while a senior White House aide reported that President Reagan intended to "use all his resources" to gain confirmation for Judge Bork. ${ }^{6}$ In contrast to public statements about other domestic policies, public statements about Supreme Court nominees always present the president's position in unambiguous terms, and the mass media tend not to alter the frame with which presidents discuss their nominees. There is some evidence that this strategy works. Krutz, Fleisher, and Bond (1998) find that the length of the speech made by the president at the time of nomination is a significant predictor of whether or not the nominee will eventually win confirmation. This is an important finding and one that supports the analysis we conduct below. We note, however, that our analysis of this process differs from the approach taken by Krutz, Fleisher, and Bond in two important respects. First, we consider all statements made by presidents on behalf of the nominee in addition to those made at the time of nomination. We believe this strategy allows us to capture the extent to which presidents continue to engage

\footnotetext{
${ }^{5}$ Nixon and Senator William Saxbe apparently agreed on a plan by which Nixon would author a letter to Saxbe explaining why Saxbe and his colleagues should support Carswell. The plan called for Saxbe to announce that Nixon's letter had persuaded him to support Carswell, with the hope that the subsequent public release of the letter would persuade other Senators to follow Saxbe's lead. As Massaro (1990, 117-19) argues, this plan backfired as many senators took offense at the tone of Nixon's letter. In fact, Minority Leader Scott warned that "one more stunt like that and Carswell will get two votes." Thus, this instance of "going public" by Nixon bolstered opposition to Carswell rather than helping secure confirmation.

${ }^{6}$ Quoted in The Washington Post, July 30, 1987, page A5.
} 
the Senate publicly during the confirmation process. Second, we explore the extent to which the political circumstances facing the president during the confirmation battle may have an influence on his decision to go public.

Thus, we argue that the nature of Supreme Court nominations mitigates the limitations and risks of the "going public" strategy. The Senate has historically been very sensitive about protecting its rights in executive/congressional conflicts, which means that presidents need not worry about getting Supreme Court nominations on the Senate agenda. Further, once a nominee is forwarded to the Senate there is no room for compromise; a nomination is an ultimatum from the president and the Senate must either accept or reject the nominee. ${ }^{7}$ As Watson and Stookey argue in their thorough analysis of the Supreme Court confirmation politics:

There are no deals, [and] no compromises ... More often than not the confirmation process also anticipates a single vote - to confirm or reject the nominee. There are no amendments, no riders, and lately no voice votes; there is no place for the senators to hide. There are no outcomes where everybody gets a little bit of what they want. There are only winners and losers. $(1995,19)$

Given the stakes involved in the Supreme Court confirmation process combined with the winner-take-all, and highly public, nature of this process, there is reason to expect presidents to view "going public" as a potential resource. As a result, they will use this strategy to help secure confirmation for their most highly prized nominees.

\section{The Supreme Court Nomination and Confirmation Game}

Existing theoretical accounts of Supreme Court nominations and Senate confirmation votes teach scholars a great deal about interactions between the president and the Senate. Most generally, Mackenzie (1981) explores the political exchanges for all executive nominations, while Watson and Stookey (1995) analyze this political process for Supreme Court nominations. More recently, Bell (2002) investigates the extent to which the increasing activity of interest groups have made the nomination and confirmation process more contentious overall and more difficult for presidents to get their nominees confirmed. Other scholars provide systematic evidence that supports these general studies.

Nemacheck and Wahlbeck focus on the initial phase of the process in their analysis of factors that presidents consider when creating short lists of possible nominees. They find that presidents' choices are "related to efforts to reduce uncertainty over the nominee's future behavior on the Court" (1998, 20). More importantly for our study, Nemacheck and Wahlbeck provide evidence that these choices are strategic because presidents account for the political environment generally and for how the Senate may react to a nomination specifically. In other words, the ideological relationship between the president, the nominee, and the

\footnotetext{
${ }^{7}$ We include sustained filibusters in our definition of votes to reject nominees.
} 
Senate plays a key role in the president's decision of whom to place on the short list.

Other theoretical and empirical work explores the president's explicit choice of nominees. This research focuses on the spatial dynamics of the confirmation game and finds that the alignment of the pivotal players (the President, the Senate, and the Court median) along an ideological continuum allows scholars to accurately predict the ideology of a president's chosen nominee (Moraski and Shipan 1999). Additionally, scholars have learned a great deal about what drives aggregate Senate action on Supreme Court nominees, as well as what drives individual senators' confirmation votes. Binder and Maltzman (2002) suggest that the presence of divided government slows the confirmation process for lower court nominees, while Segal (1987) finds that confirmation battles are as much about partisanship as they are about a struggle between the Senate and the president. Further, Massaro (1990) observes that ideological differences between the nominee and the Senate play a major role in almost all failed nominations. In line with Nemacheck and Wahlbeck's (1998) findings, this is an important point for us because it indicates that the president must consider how the Senate will react to the ideology of a chosen Supreme Court nominee.

To more explicitly understand Senate action, Cameron, Cover, and Segal (1990) and Segal, Cameron, and Cover (1992) use spatial models to analyze individual level confirmation votes. Their initial findings (1990) indicate that senators' votes are a product of the spatial distance between the nominee and a senator, a nominee's qualifications, and the political strength of the president. Segal, Cameron, and Cover (1992) correct for a shortfall in their earlier work by including a measure of interest group involvement in their model. Importantly, they continue to find strong support for the hypothesis that senators' confirmation votes largely depend on the spatial distance between a nominee and the ideology of a senators' constituency.

Overall, this literature demonstrates that the ideological relationships between the nominee and the Senate, and president and the Senate, plays a key role in the choices that presidents make during the Supreme Court nomination process. Specifically, Nemacheck and Wahlbeck (1998) and Segal (1987) find that presidents consider how the Senate will react to their choice of Supreme Court nominees. Further, Moraski and Shipan (1999), Segal, Cameron, and Cover (1992), and Cameron, Cover, and Segal (1990) use spatial models to explore how the ideological relationship between presidents, nominees, and the Senate drives who wins confirmation battles. ${ }^{8}$

\footnotetext{
${ }^{8}$ Readers may wonder whether our focus on the Supreme Court is generalizable. Indeed, the president is much more likely to nominate lower court judges than Supreme Court justices. However, because we are interested in the most intense and, according to all presidents, the most important of their nominations, we choose to focus on the Supreme Court nomination process. Additionally, we believe the theoretical focus of our paper suits the Supreme Court nomination process best. We do realize, especially in light of recent failed nominations (i.e., Miguel Estrada), that some lower court nominees may garner support from the president similar to Supreme Court nominees. But this depends
} 


\section{Hypotheses}

Together, the two literatures discussed in the previous section lead us to several conclusions. First, "going public" is an important, albeit limited, tool that presidents can use to pursue their agenda in Congress. Second, due to the nature and importance of Supreme Court nominations, presidents should find "going public" a particularly useful tool to use in helping secure confirmation for their nominees (Krutz, Fleisher, and Bond 1998). Third, the ideological distance of the key players affects the ideology of the Supreme Court nominee (Moraski and Shipan 1999). Combining these findings leads to our general hypothesis that presidents will go public to help secure confirmation for their Supreme Court nomineesespecially when the president and the Senate cannot agree on the ideology of a particular nominee.

More specifically, the existing literature leads us to several predictions about when we expect presidents to go public to fight for their chosen Supreme Court nominee. First, we hypothesize that when the president's nominee is ideologically distant from the Senate filibuster pivot, the president will have to rely on political resources to secure confirmation. ${ }^{9}$ That is, we expect the president to be more likely to make public statements that will help his nominee win Senate approval as the ideological distance between the nominee and the pivotal senator increases. $^{10}$

Second, when the current Court's median justice (meaning the median once a seat on the Court is vacant) is ideologically distant from the pivotal senator, the president is more likely to support his nominee publicly. The logic is that the Senate will be more recalcitrant to presidential nominees in this situation and can therefore force the president to nominate someone who will move the Court ideologically closer to the Senate. Thus, if the president wants to keep the Court close to his preferred ideological point, or to move it even closer, he may have to publicly cajole the Senate into acquiescing to his choice. Third, when the president and the Senate are on opposite ends of the ideological continuum, the president's choice of nominee is severely constrained, and he may rely on factors

on the salience of the position and, in the case of Estrada, on the fact that the lower court nomination may be a "test" for the nominee's chances at confirmation to the High Court. The question of generalizability has intrigued us, however, and our ongoing research has drawn us to a comparative study of how presidents can affect lower court nominees, as well as other nonjudicial executive nominees.

${ }^{9}$ Moraski and Shipan (1999) operationalize distance using the Senate median. However, based on the work of Krehbiel (1998) we think the filibuster pivot is a more appropriate representation of the strategic dynamic facing the president in confirmation battles with the Senate. Thus we use the filibuster pivot in all of the analyses that follow. While only President Johnson's attempted elevation of Abe Fortas to Chief Justice was blocked by a filibuster, we think the anticipation of a filibuster is likely to shape a president's calculations (see Moraski and Shipan 1999 on this point).

${ }^{10}$ While a purely spatial model of this process would rely exclusively on point prediction based hypotheses, we elect not to employ this strategy because of inherent measurement error in the ideal points of the key players as well as because of the transaction costs involved in rejecting nominees. 
outside the spatial model in order to win a confirmation (Moraski and Shipan 1999). Thus, we hypothesize that when presidents are ideologically distant from the Senate they are more likely to "go public" in order to win confirmation for a Supreme Court nominee. ${ }^{11}$

We do not argue that these ideological relationships alone explain presidential and senatorial behavior on Supreme Court nominees. For instance, many of the Senate arguments against President Johnson's attempted elevation of Abe Fortas to Chief Justice surrounded the timing of the nomination (Krutz, Fleisher, and Bond 1998). As Senator Griffin (R-MI) observed, "Never before has there been such obvious political maneuvering to create a vacancy so that a 'lame duck' President can fill it ..."12 In fact, we are quite certain that, in many instances, factors outside the spatial model such as gender (O'Connor), race (Thomas), and religion (Ginsburg, Scalia) may have affected the president's choice of nominee as well as the Senate's reaction to this choice. However, the extent to which we can demonstrate aggregate patterns in spite of other factors only enhances the robustness of our theory.

Finally, we hypothesize that if presidents go public to help their nominee, their efforts should have an effect on the process - that is, going public should help their nominees win confirmation. This final prediction derives from the analysis throughout the previous section, as well as from the more general nomination and confirmation literature. We know, empirically, that presidents can help their nominees by publicly touting them during their initial nomination speeches (Krutz, Fleisher, and Bond 1998), and that success in critical nominations is tied to presidential resources (Ruckman 1993). It follows, then, that going public should increase the success rate of Supreme Court nominees.

\section{Data and Methods}

To test our hypotheses we analyze all presidential addresses and press conferences from the time a nomination is made until the Senate takes action for all Supreme Court nominees between 1949 and 1994. We code every sentence of presidential public statements, and every answer presidents give to questions from the press, that pertains to the Supreme Court during this time period. ${ }^{13}$ Appendix

\footnotetext{
${ }^{11}$ Throughout the paper, distance is operationalized as the absolute value of the difference in 1st dimension DW-NOMINATE coordinates (Poole and Rosenthal 1997).

${ }^{12}$ Quoted in Congressional Quarterly Weekly Report 1968 (1834).

${ }^{13}$ There are many potential operationalizations of this variable beyond the one we employ here. For instance, one could count speeches rather than statements. However, we believe our method is an appropriate strategy because we are interested in the exact amount and nature of support given to a nominee. In other words, we are interested in the information contained in the presidential speeches, rather than the simple fact that a nominee is mentioned. Additionally, note that our categories are mutually exclusive. This means that we do not double count statements. We do, however, count when presidents make several different statements to support their nominee in one speech (although this rarely happens). Finally, note that we estimated the same model as we present in Table 2, but substituted the number of speeches that support a nominee (excluding press conferences) for the total
} 
3 (which can be accessed at www.journalofpolitics.org) lists the dates of the public appearances that we code for this analysis. ${ }^{14}$ Using these sources we count the total number of references in presidential public statements that focus on (1) a nominee's qualifications; (2) claims of public opinion in favor of the nominee; and (3) calls for the Senate to act fairly and quickly during the confirmation process so that the Court can continue its work with a full complement of justices. $^{15}$

Examples of each category illustrate how we conducted the coding. Most often presidents make claims about the qualifications of their nominees. For instance, President Johnson said Thurgood Marshall “. . . is best qualified by training and by very valuable service to the country. I believe it is . . the right man in the right place" (Johnson 1967). Comments about public opinion are exemplified by President Reagan's support for Robert Bork: "And if the people want a measure of how the American public feels on the nomination of Robert Bork to the Supreme Court, they should ask ... about the 72,000 petitions, pro-Bork petitions, that have flooded in over the last 3 weeks - with more coming in all the time" (Reagan 1987). Finally, President Nixon publicly called on the Senate to “. . . approve their (Lewis Powell and William Rehnquist) nominations promptly, so that the Court can move forward in the backlog of cases that is building up

number of statements. These results (available upon request) are actually stronger than those presented in Table 2. Even so, we use our original model because we believe it is more theoretically appropriate.

${ }^{14}$ One could also quibble with combining public speeches and press conferences. After all, when presidents give a speech it is their choice to go public, but when they are asked questions at a press conference their responses may be dictated by the questions that are asked and/or the other news of the day. Thus, a president may have a more limited opportunity to be strategic. However, we argue that presidents maintain control over the answers given to press conference questions such that they use their answers to support their nominees. In fact, as we note below, President Truman refused to answer questions about nominees at press conferences. Hence it seems that the press cannot force a president to "go public" against his will or, for that matter, control the direction or content of president's answers to questions about nominees. Empirically, our dependent variable is actually dominated by statements made in speeches and not by answers to media questions. In a difference of means test between the two types of statements that make up our dependent measure, statements made in public speeches clearly dominate answers given at press conferences (the difference is significant at the .02 level). Finally, note that during press conferences we found no instances of multiple questions. Thus, our measure is not over-inflated by the fact that we include press conferences in the count. Overall, the reason we include press conferences, even though they comprise a very small portion of our dependent variable (41 of the 220 data points for this variable) is that we believe the object of the statements (public pressure on the Senate) is not necessarily affected by the venue of the statement. That is, we see no reason to expect answers to questions to have a different effect on the public and the Senate than speeches do. The important concept is that the presidential message is communicated to the public. However, as noted in footnote 13, excluding press conferences does not change the substantive results of our model.

${ }^{15}$ The reader should note that we do not include statements that focus on the facts about a nominee. These include statements presidents make about where a nominee attended law school, which lower courts a nominee served on, or what the nominee has done prior to nomination. We are only interested in statements that defend the nominee. 
TABLE 1

The Frequency of Presidential Political Capital Statements about Supreme Court Nominees (by type of comment)

\begin{tabular}{|c|c|c|c|c|}
\hline Nominee & President & Qualifications & $\begin{array}{l}\text { Public } \\
\text { Opinion }\end{array}$ & $\begin{array}{l}\text { Senate } \\
\text { Pressure }\end{array}$ \\
\hline Clark & Truman & 0 & 0 & 0 \\
\hline Minton & Truman & 0 & 0 & 1 \\
\hline Warren & Eisenhower & 2 & 0 & 1 \\
\hline Harlan & Eisenhower & 1 & 0 & 2 \\
\hline Brennan & Eisenhower & 0 & 0 & 0 \\
\hline Whittaker & Eisenhower & 0 & 0 & 0 \\
\hline Stewart & Eisenhower & 0 & 0 & 0 \\
\hline White & Kennedy & 2 & 0 & 0 \\
\hline Goldberg & Kennedy & 1 & 0 & 0 \\
\hline Fortas (1) & Johnson & 1 & 1 & 0 \\
\hline Marshall & Johnson & 4 & 0 & 0 \\
\hline Fortas (2) & Johnson & 2 & 0 & 0 \\
\hline Burger & Nixon & 3 & 1 & 0 \\
\hline Haynsworth & Nixon & 8 & 1 & 4 \\
\hline Carswell & Nixon & 1 & 0 & 2 \\
\hline Blackmun & Nixon & 0 & 0 & 0 \\
\hline Powell & Nixon & 3 & 0 & 2 \\
\hline Rehnquist (1) & Nixon & 3 & 0 & 2 \\
\hline Stevens & Ford & 2 & 0 & 1 \\
\hline O'Connor & Reagan & 3 & 0 & 0 \\
\hline Scalia & Reagan & 10 & 0 & 3 \\
\hline Rehnquist (2) & Reagan & 10 & 0 & 3 \\
\hline Bork & Reagan & 28 & 9 & 33 \\
\hline Kennedy & Reagan & 7 & 0 & 5 \\
\hline Souter & Bush & 11 & 2 & 6 \\
\hline Thomas & Bush & 12 & 12 & 5 \\
\hline Ginsburg & Clinton & 4 & 1 & 2 \\
\hline Breyer & Clinton & 3 & 0 & 0 \\
\hline Total & & 121 & 27 & 72 \\
\hline
\end{tabular}

because of the two vacancies which have occurred in recent weeks" (Nixon 1971). Table 1 presents the frequency with which each president made public statements that fall into these categories. Clearly the majority of public statements concern a nominee's qualifications, but presidents do invoke statements about public support for their choices, as well as statements meant to pressure the Senate. ${ }^{16}$

\footnotetext{
${ }^{16}$ We expected the president to use other types of statements as well. For instance, we thought presidents would argue that during their honeymoon period the Senate should acquiesce to their choices or that presidents with high approval ratings should be able to nominate whomever they please to the Supreme Court. We did not find any evidence that presidents spoke publicly about these factors.
} 
Because our dependent variable is a discrete measure we cannot use traditional linear regression to model this phenomenon. As Long points out, "The use of LRM models for count outcomes can result in inefficient, inconsistent, and biased estimates" (1997, 217). These are not just statistical problems, however. Rather, King $(1988,846)$ argues that these shortfalls often result in substantive problems where coefficients are the wrong size and the wrong sign. While many reasonable alternatives to OLS regression have been suggested for models with discrete independent variables, King's (1989) generalized event count model (GEC) allows researchers to model discrete events when unknown dispersion exists in the dependent variable. ${ }^{17}$ Additionally, King $(1988,859)$ points out that his technique allows researchers to analyze very small samples (even with an $\mathrm{N}$ as small as 10). Thus, his GEC model is appropriate for our purposes.

The model includes three independent variables to test our hypotheses. First, we calculate the absolute value of the distance between the nominee's ideology and the ideological score of the Senate filibuster pivot. ${ }^{18}$ For the nominee's ideology we utilize Segal/Cover scores that are converted to a $0-1$ scale (Epstein and Mershon 1996, 269). ${ }^{19}$ For the filibuster pivot we use DW-NOMINATE scores. ${ }^{20}$ We expect that as this distance increases the president will have a more

\footnotetext{
${ }^{17}$ While a Poisson model is also an appropriate modeling choice for count outcomes, the data we employ do not lend themselves to this technique. Indeed, the variance of the dependent measure is 13.86, which is greater than its mean of 8.07. This means that the Poisson model would produce consistent but inefficient estimates as well as downwardly biased standard errors (Long 1997, 230). We could also use a Negative Binomial Regression model (Long 1997; Greene 2003) which accounts for overdispersion by allowing "the conditional variance of $y$ to exceed its conditional mean" (Long 1997, 230). However, because we did not have a priori expectations for model dispersion, King's generalized event count is the most flexible and appropriate model for these data.

${ }^{18}$ Using the filibuster pivot comports with Krehbiel's (1998) theory of "pivotal politics," which holds that supermajoritarian institutions - such as the Senate filibuster and the presidential vetohave an important influence on the legislative process because policy makers often must obtain large supermajority coalitions to secure passage of legislation. Moraski and Shipan explain why the filibuster is pivotal explicitly during the nomination process: "The reason for this...is that the Senate can filibuster on a nomination, a tactic that the president will need to take into account. While the use of the filibuster for a Supreme Court nomination is a rare event, its infrequency does not denote its unimportance" $(1999,1093)$.

${ }^{19}$ The reader should note that our measures of ideal points (DW-NOMINATE scores and Segal/Cover scores) might not be based on an identical policy space. That is, while both sets of scores have face validity-DW-NOMINATE represents Senator Ted Kennedy as being very liberal and Segal/Cover scores show Justice Antonin Scalia as a staunch conservative-we cannot be sure that a specific Segal/Cover score maps directly onto the DW-NOMINATE space. However, measures that correct this problem do not have measures of ideology for rejected nominees and are wrought with so much imprecision as to make empirical inference impossible (Bailey 2002; Bailey and Chang 2001). To test whether these cross institutional measures change our results, we estimated the model with them in place of the Segal/Cover and DW-NOMINATE scores. The substantive results, presented in Appendix 2 (available at www.journalofpolitics.org) do not change.

${ }^{20}$ Other work in this area (Moraski and Shipan 1999) has used adjusted ADA scores to model the dynamics of this game. However, we think DW-NOMINATE scores are more appropriate for this type of analysis for a number of reasons. DW-NOMINATE scores are constructed using an overwhelming majority of the roll-call record (only unanimous and near-unanimous votes are excluded—see Poole
} 
difficult time securing confirmation and will therefore be more likely to make public statements that support the nominee.

Second, to test whether the ideological distance between the Senate and the current Court (based on the eight remaining justices when a vacancy occurs) affects the president's decision to go public, we calculate the absolute value of the difference between the filibuster pivot's ideology and the ideology of the Court median. Finally, we calculate the absolute value of the distance between the president's own ideology and the ideological score of the Senate filibuster pivot. To determine this distance we utilize DW-NOMINATE scores for the president and the pivotal Senator in the year that a nomination takes place. ${ }^{21}$ These variables should have significant and positive relationships with a president's decision to pressure the Senate publicly during the confirmation process.

Beyond the spatial measures, we include two necessary control variables. First, we must consider whether the president's public role in the confirmation process has changed over time. When we ran a GEC model for the president's propensity to pressure the Senate publicly on year, we find a strong time trend. Controlling for no other factors, the year variable predicts that President Truman would make an average of 2.09 statements per nominee, whereas it predicts an average of 20.25 statements per nominee for President Clinton. Our model therefore includes a measure for time as a control variable that is coded as the year of nomination. Second, the time period between a nomination and Senate action varies as well. Some nominations simply take longer than others due to scheduling problems or controversy. Thus, we include the natural log of the time (in days) between a nomination and Senate action to account for the theoretical maximum number of statements a president could make (see King 1988).

In general, we expect the president to go public when he is ideologically constrained by the Senate. At the same time, we must also account for whether strong presidents publicly pressure the Senate at the same rate as weak presidents. To test whether a difference exists, we include three additional controls in the model that account for political resources held by the president at the time a nomina-

and Rosenthal (1997) for further details), whereas the ADA selects only 20 "key votes" for each calendar year. While the two sets of scores are highly correlated ( $r>.9$ for most Congresses), DWNOMINATE scores are less sensitive to missed votes and strategic manipulation. By design, the ADA chooses votes that will separate perceived "liberals" from "conservatives," which Arnold $(1990,82)$ notes can lead to cases where legislators intentionally vote against the ADA position to ensure that they do not receive a "perfect" ADA score, which might attract potential challengers. The DW-NOMINATE procedure clearly precludes this type of behavior from severely contaminating the analysis. Note that using ADA scores rather than DW-NOMINATE does not alter any of our substantive findings.

${ }^{21}$ Note that our hypotheses about these ideological distance variables are conditional on the nominee not being in the Senate's winset. That is, if a president nominates someone who will move the Court in the direction of the Senate then the Senate should confirm the nominee without presidential prodding. However, the only nominee in our data that is in the Senate winset is Stephen Breyer - and he sits on the edge of the winset. We elected to include Breyer in the analysis for the sake of completeness, but the substantive results of the model do not change if he is excluded. 
tion is made. First, we include a measure of the president's public approval rating at the time of the nomination. Second, we include a measure of qualifications for each nominee to account for the fact that presidents may find it easier to sell highly qualified nominees by going public. ${ }^{22}$ Finally, we include a measure of the number of years a president has left in his current term to control for "honeymoon" or "lame-duck" effects (Massaro 1990). ${ }^{23}$

\section{Results}

Table 2 presents the results of the GEC model with the number of references to political capital as the dependent variable. ${ }^{24}$ Parameter estimates for our three ideological distance variables are in the hypothesized direction and statistically significant. These results indicate that as the distance between the nominee and the pivotal Senator increases, the president is more likely to invoke public statements on behalf of a nominee. The same relationship holds for the distance between the Court median and the pivotal Senator, which suggests that presidents are more likely to use political capital when trying to sell a nominee who will not move the Court closer to the pivotal Senator's preferred position. Finally, as the distance between the president's own ideology and the pivotal Senator increases, the president is more likely to make public statements in support of a nominee. Thus, as we expected, the ideological alignment of the key institutional players has a clear effect on the presidents' propensity to go public during this process. ${ }^{25}$

Our statistical findings also have clear substantive meaning. Holding all other variables at their mean value, the predicted number of public statements that

\footnotetext{
${ }^{22}$ Qualifications are based on scores derived from the Supreme Court Compendium (Epstein et al. 1996, 329). Like Segal/Cover Scores that measure the ideology of Supreme Court nominees, the qualifications measure is based on a content analysis of editorial judgments about the nominees in four major newspapers (two liberal leaning papers - the New York Times and the Washington Post, and two that lean conservative-The Chicago Tribune and the Los Angeles Times).

${ }^{23}$ Descriptive statistics for each of these variables can be accessed in Appendix 1 (available at www.journalofpolitics.org).

${ }^{24}$ In Appendix 2 (available at www.journalofpolitics.org), we report the findings for the GEC model without the outlier (Bork), as well as the results of negative binomial regression models with and without the Bork nomination included. We also provide results using an alternative measure for ideology - the Bailey/Chang scores discussed in footnote 19. We do so to demonstrate the robustness of the findings even without the outlying observation included in the model, and when using alternative modeling or measurement techniques.

${ }^{25}$ The reader could argue that these variables do not fully capture the conditions under which the president would go public. Indeed, it is possible that the ideological distance variables do not actually measure whether a nominee is in trouble in the Senate. To test this hypothesis we ran our model with an additional variable: the predicted number of "no" votes the president could expect in the Senate (Segal and Spaeth 2002, 216). Doing so does not change our results - in fact the revised model produces even more precise estimates for our key variables, while the new control variable does not reach an acceptable level of statistical significance (results available at www.journalofpolitics.org). In short, even when controlling for this plausible alternative explanation our model holds. We do not include this variable in the reported model due to the loss of two observations (Clark and Minton) and because we believe that our model in Table 2 captures the essential dynamics of the process.
} 
TABLE 2

Generalized Event Count Regression Model of a President's Public Invocation of Political Resources

\begin{tabular}{lc}
\hline Variable & $\begin{array}{c}\text { Coefficient } \\
\text { (Standard Error) }\end{array}$ \\
\hline Ideological Distance between & $2.35^{*}$ \\
Nominee and Filibuster Pivot & $(.79)$ \\
Ideological Distance between & $2.84^{*}$ \\
Court Median and Filibuster Pivot & $(1.27)$ \\
Ideological Distance between & $5.08^{*}$ \\
President and Filibuster Pivot & $(3.18)$ \\
Presidential Approval at time of & $-2.92^{*}$ \\
Nomination & $(1.87)$ \\
Nominee Qualifications & .25 \\
& $(.46)$ \\
Years Remaining in Office For & .88 \\
President & $(.84)$ \\
Year of Nomination & $.06^{*}$ \\
Natural Log of Time Between & $(.01)$ \\
Nomination and Senate Action & $2.70^{*}$ \\
Intercept & $(.97)$ \\
Gamma Estimate & $-116.31^{*}$ \\
Log-Likelihood & $(24.41)$ \\
Number of Cases & $.92^{*}$ \\
\hline
\end{tabular}

${ }^{\text {a }}$ A significant gamma indicates that the model is overdispersed.

$*=p<.10$.

presidents make to support their nominees ranges from a low of 1.43 to a high of 6.16 as the distance increases between the nominee and pivotal Senator. In other words, presidents who nominate someone who is ideologically distant from the Senate are almost five times as likely to go public to fight for their chosen nominee. Similarly, the predicted number of public statements varies from 2.34 to 6.45 as the distance between the current Court median and the pivotal Senator increases from its lowest to highest observed value. Thus, presidents invoke almost three times as many public statements when their nominee will not move the Court median ideologically closer to the pivotal Senator. Finally, the predicted number of public statements varies from a low of 2.16 to a high of 4.76 as the distance between the president and the pivotal Senator moves from its minimum to its maximum value.

Instances of specific behavior by presidents further buttress the empirical results presented in Table 2. Most of these accounts demonstrate that the use of 
public statements is conditional on both the ideology of the nominee and the ideological alignment of the Court and the Senate. After failing to secure the confirmation of Robert Bork President Reagan, claiming that experience had made him wiser, nominated a known moderate in Anthony Kennedy. Reagan's behavior reflects this change in nominee ideology. After making an unprecedented 70 public statements on behalf of Bork, Reagan made only 12 statements to support Kennedy. Similarly, President G. H. W. Bush made 10 fewer statements on behalf of David Souter than he did on behalf of Clarence Thomas, despite facing similar constraints from the Democratically controlled Senate. The key point is that Bush's two nominees had differing ideologies. Indeed, Souter was considered moderate and, as Abraham (1999) notes, was chosen in part because he was unlikely to generate controversy, whereas Thomas was considered a staunch conservative.

President Clinton's experience is also indicative of a president choosing not to pursue nominees with a strong ideological bent. Clinton passed over liberal cabinet member Bruce Babbitt twice in favor of Ruth Bader Ginsburg and Stephen Breyer-both moderates who were unlikely to generate Senate opposition. ${ }^{26}$ In fact, some reports suggest that Clinton deliberately selected moderates to avoid costly confirmation battles so that he could save his political capital for issues such as health care reform. ${ }^{27}$ Given the ideological moderation of his nominees it is not surprising that the usually verbose President Clinton made few statements on behalf of Ginsburg and Breyer. And, ultimately, both nominees enjoyed smooth sailing in the Senate.

President Nixon's behavior is also consistent with our model. After his acrimonious public battle with the Senate over the nominations of Clement Haynsworth and Harrold Carswell, President Nixon abandoned his "southern strategy" when he selected Harry Blackmun. Blackmun, much like Souter, Kennedy, Ginsburg, and Breyer, was a moderate who was expected to generate little opposition. This is evidenced by the fact that President Nixon made no public statements on Blackmun's behalf. ${ }^{28}$

Turning to the control variables, it is clear that presidential approval has a negative effect on the number of public statements made by the president. This suggests that very popular presidents do not have to expend as much capital to secure confirmation for their preferred nominee (even controlling for ideological distance), as do unpopular presidents. Substantively, the predicted number of statements varies from 5.88 at the lowest observed level of approval to 1.88 at the highest observed level of approval. This result is consistent with the "win at all

\footnotetext{
${ }^{26}$ Clinton was reportedly warned that Babbitt would encounter "stiff opposition" from conservatives as well as from Western Senators opposed to his views on land usage (Abraham 1999; Idelson 1994a).

${ }^{27}$ See Idelson (1994c).

${ }^{28}$ Of course we do not claim that Nixon's lack of public statements on behalf of Blackmun should be entirely attributed to ideology. Indeed, Nixon may simply have been gun-shy about going public for Blackmun after his public support of Carswell was met with great resistance in the Senate.
} 
costs" view of Supreme Court nominations discussed earlier. Despite considerable evidence that the effectiveness of presidential speeches declines along with presidential approval (Ragsdale 1984), these data suggest that presidents may try to make up for the lack of effectiveness by increasing quantity or, in the case of President Clinton, choosing noncontroversial nominees. Finally, the model reveals no discernible effect from nominee qualifications or years remaining in the president's term on the frequency of presidential public statements.

\section{The Impact of Going Public}

While we have provided both statistical and substantive evidence that presidents go public to support their Supreme Court nominees, we do not yet know whether presidents can actually help their nominees do better by going public after the nomination has been sent to the Senate. To test our final hypothesis we regress the difference between the predicted number of votes against confirmation and the actual number of no votes each nominee received in the Senate (Segal and Spaeth 2002,216) on the president's use of public statements (the dependent variable in Table 2). ${ }^{29}$ We expect a positive relationship between these variables because if going public is an effective strategy for presidents we would expect the Senate to cast fewer no votes than predicted. We also included a variable to measure the time that elapses between nomination and Senate action, as well as a variable for the year of nomination. Our intuition for the former variable is that longer confirmation battles often arise because something unforeseen in the nominee's background might cause more "no" votes than predicted by Segal and Spaeth's model. For the latter we expect more political, and therefore more controversial, nominations in recent years. Thus, we expect a negative sign on both of these variables (meaning more no votes than actually is predicted). ${ }^{30}$

\footnotetext{
${ }^{29}$ The predicted no votes are derived from Segal and Spaeth's $(2002,216)$ model of individual senator's confirmation votes, where the independent variables used to predict "no" votes are nominee ideology (Segal/Cover scores), nominee qualifications, ideological distance between nominee and each Senator, presidential strength in the Senate (Senate party control), presidential approval, and the extent of interest group activity for and against a nominee. The actual no votes are also taken from Segal and Spaeth. The dependent variable is the difference between the two. For example, the observation on our impact variable for Justice Thomas is 8 (56 predicted no votes minus 48 actual no votes). Thus, a positive sign on this variable indicates fewer no votes than predicted, while a negative sign means more no votes than predicted. Note that we use an OLS model here, instead of a GEC or another count model, because we have negative values in our dependent variable. Thus, these other models cannot be used.

${ }^{30}$ Certainly there may be some endogeneity in this process - meaning that the dependent variable (difficulty in the Senate) might be affecting the main independent variable (the president's propensity to go public). We control for this to a large extent with the variable that measures time from nomination to a final confirmation vote is taken. As argued above this variable acts as a proxy for the level of contention encompassed by the confirmation process. Additionally, using the predicted number of no votes as part of the dependent measure allows us to distinguish between ex ante support/opposition for a nominee and support induced through presidential persuasion or opposition as a result of revelations occurring during the confirmation process. Thus, while this is a difficult problem with which to deal, we are confident that we are capturing what is actually happening in this process.
} 
TABLE 3

OLS Regression of the Impact of President's Public Statements on Senate Confirmation Votes

\begin{tabular}{lc}
\hline Variable & $\begin{array}{c}\text { Coefficient } \\
\text { (Standard Error) }\end{array}$ \\
\hline Number of Public Statements & $.47^{*}$ \\
made by the President & $(.19)$ \\
Natural Log of Time Between & $-9.17^{*}$ \\
Nomination and Senate Action & $(3.54)$ \\
Year of Nomination & -.04 \\
& $(.10)$ \\
Intercept & 98.52 \\
Number of Cases & $(192.48)$ \\
Adjusted $\mathrm{R}^{2}$ & 25 \\
\hline
\end{tabular}

$*=p<.10$.

Table 3 strongly confirms our hypothesis that when presidents publicly support their nominee the number of no votes cast is significantly fewer than the number Segal and Spaeth's model predicts. ${ }^{31}$ Even when we account for the fact that a nomination may be a particularly difficult one, as well as for the year of nomination, it is evident that the strategy to go public directly affects the likelihood that a nominee will win. ${ }^{32}$ In the case of Clarence Thomas our model suggests that President Bush's 29 public statements in support of confirmation are associated with a gain of six votes for Thomas over what the Segal/Spaeth model predicts - which was enough to secure confirmation. ${ }^{33}$ The bottom line is that there is a definite relationship between a president's strategy to go public and the fate of that nominee when the Senate finally takes action.

\section{Conclusion}

On January 30, 2003 - almost two years after his initial nomination-the Senate Judiciary committee forwarded the nomination of Miguel A. Estrada,

\footnotetext{
${ }^{31}$ Robert Bork had to be excluded from this model because by any diagnostic measure he is an influential outlier. For an explanation, and for our outlier analysis, see Appendix 4 (available at www.journalofpolitics.org).

${ }^{32}$ Some might argue that we have underspecified the model because we did not include such variables as nominee qualifications or presidential capital. However, as footnote 29 indicates, all of these variables are included on the left side of the equation because they make up Segal and Spaeth's predicted Senate votes. Thus, we cannot include them on the right side of the equation.

${ }^{33}$ Segal and Spaeth predicted 56 votes against Thomas while only 48 actually occurred. Admittedly, we cannot determine definitively whether Bush's public strategy directly led to the Thomas confirmation. However, as we argue in the theory section, we believe the Supreme Court nomination and confirmation process does not involve a great deal of backroom dealings or compromise after the nomination occurs.
} 
nominee for the D.C. Circuit Court of Appeals, to the full Senate for consideration. On September 4, 2003, after seven failed cloture votes on his nomination, Estrada withdrew his name from consideration. Despite the fact that the battle is now over, it is seen by many as a harbinger of things to come - as there is open speculation that President G. W. Bush would like to ultimately nominate Estrada to the U.S. Supreme Court. ${ }^{34}$ The important point for our analysis is that, despite the successful filibuster waged by the Senate Democrats, the White House never backed down, and continued to apply a great deal of public pressure on the Senate until the bitter end. As Dewar (2003) points out, President Bush personally went public on several occasions accusing Senate Democrats of "shameful politics" and declaring, "fairness demands that he receive an up or down vote on the Senate floor [as quickly as possible]." ${ }^{\prime 35}$ In short, President Bush responded to the Senate filibuster as our model predicts - rather than accepting the apparent reality that there were not enough votes to break the filibuster on Estrada, he continued to exert public pressure on the Senate in hopes of changing votes. We have provided evidence that is consistent with the Bush administration's current strategy. That is, we provide a general explanation of how and when presidents choose to exercise their political capital by "going public" to support their nominations to the United States Supreme Court. This comports with, and adds to, Maltese's argument that presidents have developed:

... their own strategic resources to help secure confirmation of their judicial nominees, resources used to "sell" their Supreme Court nominees. Presidents now have an unprecedented ability to communicate directly with the American people, to mobilize interest groups, and to lobby the Senate. $(1995,11)$

We confirm Maltese's argument by demonstrating that, at least since 1970, presidents have effectively used public statements to pressure the Senate by publicly selling their nominees.

At the same time, our findings add to the recent empirical works that seek to explain how presidents choose the ideology of nominees to the United States Supreme Court (Moraski and Shipan 1999). Moraski and Shipan show how presidents often win confirmation battles by nominating individuals whom the Senate will not object to ideologically. What they do not determine, however, is when presidents will actually invoke their political resources in a public manner to fight for their chosen nominees. The findings in this paper do so.

At the end of the day, most presidents probably feel the way President Nixon did when he faced a hostile Senate, and most senators probably believe what Senator Leahy argued after the Pickering nomination process. What we demonstrate is that while the Senate does advise and consent on Supreme Court nomi-

\footnotetext{
${ }^{34}$ Judiciary Committee Chairman Orrin Hatch made this point bluntly arguing, "They (Democrats) know he (Estrada) is on the fast track for the Supreme Court, and that's what they are worried about."

${ }^{35}$ The President's full comment was that "Miguel Estrada is highly qualified, extremely intelligent. $\mathrm{He}$ has the votes necessary to be confirmed. Yet a handful of Democrats in the Senate are playing politics with his nomination, and it's shameful politics" (Dewar 2003).
} 
nations, presidents will do anything-including going public to support their nominees - in an attempt to make the consensual aspect of the Senate's role much more likely.

\section{Acknowledgments}

We thank Charles Shipan and Stephen M. Caliendo for generously sharing data for this analysis, as well as Steve Smith, Lee Epstein, Jamie Carson, Eliot Slotnick, and Sam Lopeman for their helpful comments on earlier drafts of the paper. We also thank Joanne Miller, Chris Federico, and Sam Luks for helpful methodological advice. The appendices and data used for this paper can be obtained from the Journal of Politics web site (http://www.journalofpolitics.org).

Manuscript submitted June 3, 2003

Final manuscript received October 14, 2003

\section{References}

Abraham, Henry J. 1999. Justices, Presidents, and Senators: A History of U.S. Supreme Court Appointments from Washington to Clinton. New York: Rowman \& Littlefield.

Arnold, R. Douglas. 1990. The Logic of Congressional Action. New Haven: Yale University Press.

Bailey, Michael. 2002. “Comparing Presidents, Senators, and Justices, 1946-2000.” Paper presented at Washington University Ideal Point Estimation Conference. Available for download at http://adm.wustl.edu.

Bailey, Michael, and Kelly H. Chang. 2001. "Comparing Presidents, Senators, and Justices: Interinstitutional Preference Estimation." Journal of Law, Economics, and Organization 17 (October): 477-506.

Bell, Lauren Cohen. 2002. Warring Factions: Interest Groups, Money, and the New Politics of Senate Confirmation. Columbus: The Ohio State University Press.

Binder, Sarah A., and Forrest Maltzman. 2002. "Senatorial Delay in Confirming Federal Judges, 1947-1998." American Journal of Political Science 46(1): 190-99.

Brace, Paul, and Barbara Hinckley. 1993. "Presidential Activities from Truman through Reagan." The Journal of Politics 55(2): 382-98.

Cameron, Charles M., Albert D. Cover, and Jeffrey A. Segal. 1990. "Senate Voting on Supreme Court Nominees: A Neoinstitutional Model." American Political Science Review 84(2): 525-34.

Cohen, Jeffrey E. 1995. "Presidential Rhetoric and the Public Agenda." American Journal of Political Science 39(1): 87-107.

Congressional Quarterly Weekly Report. 1968.

Dewar, Helen. 2003. "Democrats Demand More Information on Estrada; Senators Threaten Filibuster to Block Bush Nominee.” Washington Post. February 12: A04.

Edwards, George III, and B. Dan Wood. 1999. "Who Influences Whom? The President and the Public Agenda." American Political Science Review 93(2): 327-44.

Epstein, Lee, and Carol Mershon. 1996. "Measuring Political Preferences." American Journal of Political Science 40(1): 260-94.

Epstein, Lee, Jeffrey Segal, Harold Spaeth, and Thomas Walker. 1996. The Supreme Court Compendium. Washington: Congressional Quarterly Press.

Greene, William H. 2003. Econometric Analysis. Upper Saddle River, NJ: Prentice Hall.

Idelson, Holly. 1994a. "From 'Wealth of Talent,' Clinton Picks Breyer." Congressional Quarterly Weekly Report: 1213. 
Idelson, Holly. 1994b. "Breyer's Liberal, Conservative Mix Seems to Assure Confirmation." Congressional Quarterly Weekly Report: 1305.

Idelson, Holly. 1994c. "Breyer's Bipartisan Appeal Extinguishes Fireworks." Congressional Quarterly Weekly Report: 1861.

Johnson, Lyndon B. 1967. "Remarks to the Press Announcing the Nomination of Thurgood Marshall as Associate Justice of the Supreme Court." June 13.

Kernell, Samuel. 1997. Going Public: New Strategies of Presidential Leadership, 3rd ed. Washington: CQ Press.

King, Gary. 1988. "Statistical Models for Political Science Event Counts: Bias in Conventional Procedures and Evidence for the Exponential Poisson Regression Model." American Journal of Political Science 32(3): 838-63.

King, Gary. 1989. "Variance Specification in Event Count Models: From Restrictive Assumptions to a Generalized Estimator." American Journal of Political Science 33(3): 762-84.

Krehbiel, Keith. 1998. Pivotal Politics: A Theory of U.S. Law Making. Chicago: University of Chicago Press.

Krutz, Glen, Richard Fleisher, and Jon Bond. 1998. "From Abe Fortas to Zoe Baird: Why Some Presidential Nominations Fail in the Senate." The American Political Science Review 92(4): 871-81.

Long, J. Scott. 1997. Regression Models for Categorical and Limited Dependent Variables. Thousand Oaks: Sage Publications.

Maltese, John A. 1995. The Selling of Supreme Court Nominees. Baltimore: Johns Hopkins University Press.

Massaro, John. 1990. Supremely Political: The Role of Ideology and Presidential Management in Unsuccessful Supreme Court Nominations. Albany: State University of New York Press.

Mackenzie, G. Calvin. 1981. The Politics of Presidential Appointments. New York: Free Press.

Mackenzie, G. Calvin. 2001. Innocent Until Nominated: The Breakdown of the Presidential Appointments Process. Washington: Brookings Institution.

Moraski, Byron J., and Charles R. Shipan. 1999. "The Politics of Supreme Court Nominations: A Theory of Institutional Constraints and Choices." American Journal of Political Science 43(3): 1069-95.

Nemacheck, Christine, and Paul Wahlbeck. 1998. "The President's Choice of a Supreme Court Nominee." Presented at the annual meetings of the Midwest Political Science Association.

Neustadt, Richard E. 1990. Presidential Power and the Modern Presidents: The Politics of Leadership from Roosevelt to Reagan New York: Free Press.

Nixon, Richard M. 1971. "Address to the Nation Announcing Intention to Nominate Lewis F. Powell Jr., and William H. Rehnquist to be Associate Justices of the Supreme Court of the United States." October 21.

Ostrom, Charles W., and Dennis M. Simon. 1988. "The President's Public." American Journal of Political Science 32(4): 1096-1119.

Poole, Keith, and Howard Rosenthal. 1997. Congress: A Political-Economic History of Roll Call Voting. New York: Oxford University Press.

Ragsdale, Lyn. 1984. "The Politics of Presidential Speechmaking, 1949-1980.” American Political Science Review 78(4): 971-84.

Reagan, Ronald. 1987. "Remarks at the Annual Convention of Concerned Women for America." September 25.

Ruckman, P.S. 1993. "The Supreme Court, Critical Nominations, and the Senate Confirmation Process." Journal of Politics 55(3): 793-805.

Segal, Jeffrey. 1987. "Senate Confirmation of Supreme Court Justices: Partisan and Institutional Politics." The Journal of Politics 49(4): 998-1015.

Segal, Jeffrey, and Harold J. Spaeth. 2002. The Supreme Court and the Attitudinal Model Revisited. Cambridge: Cambridge University Press.

Segal, Jeffrey, Charles M. Cameron, and Albert D. Cover. 1992. "A Spatial Model of Roll Call Voting: Senators, Constituents, Presidents, and Interest Groups in Supreme Court Confirmations." American Journal of Political Science 36(1): 96-121. 
Sinclair, Barbara. 1991. "Governing unheroically (and sometimes unappetizingly): Bush and the 101st Congress.” In The Bush Presidency: First Appraisals, edited by Colin Campbell, S.J. Rockman, and Bert A. Rockman. Chatham, NJ: Chatham House Publishers.

Watson, George, and John Stookey. 1995. Shaping America: The Politics of Supreme Court Appointments. New York: HarperCollins.

Timothy R. Johnson is assistant professor of political science, University of Minnesota, Minneapolis, MN 55455 (tjohnson@polisci.umn.edu). Jason M. Roberts is assistant professor of political science, University of Minnesota, Minneapolis, MN 55455 (jroberts@polisci.umn.edu). 